\title{
The Relationship Between Interatrial Block and PASI Score in Patients with Psoriasis
}

\section{Psoriazisli Hastalarda İnteratriyal Blok ve PACİ Skoru Arasındaki İlişki}

\author{
(D) Nijad Bakhshaliyev, (D) Asım Enhoş, (D) Erdem Karaçöp, (D) Ramazan Özdemir
}

Bezmialem Vakıf University Faculty of Medicine, Department of Cardiology, İstanbul, Turkey

\section{Abstract}

Objective: The relationship between the interatrial block (IAB) and atrial fibrillation (AF) has been demonstrated in previous studies. The aim of this study is to investigate the relationship of the IAB with the psoriasis area severity index (PASI) score in psoriasis.

Method: Patients with psoriasis who were examined at the cardiology outpatient clinic between January 2017 and May 2019 were retrospectively screened. Two hundred and thirty-eight patients whose electrocardiogram (ECG) and PASI scores were available were included in the study. IAB was defined as if $P$ wave duration was equal to or longer than 120 msec with (advanced IAB) or without (partial IAB) biphasic $P$ morphology in the inferior electrocardiographic leads. The prevalence of IAB in patients with psoriasis and its relationship with the severity of psoriasis were evaluated in the present study.

Results: The mean age was 35 (18-62) years, 53\% of the study population were male. The median PASI score was 6. IAB was observed in $9.9 \%$ of patients. Partial IAB was observed in $6 \%$ of patients whereas the prevalence of advanced IAB was $3.0 \%$. No statistically significant difference was observed between the PASI score in patients with and without IAB [6.0 (3.0-13.5) vs. 7.0 (2.5-22.5), respectively, $p=0.35]$. The mean $\mathrm{P}$ wave duration (PWD) was 101 (90-111) ms. No statistically significant correlation was observed between PWD and the PASI score $(p=0.35, r=0.06)$.

Conclusion: No significant correlation was identified between IAB and the PASI score, which is used for assessing the severity of psoriasis.

Keywords: Atrial fibrillation, electrocardiography, interatrial block, psoriasis, psoriasis area severity index, stroke

\section{Öz}

Amaç: Interatriyal blok ve atriyal fibrillasyon arasındaki ilişki daha önceki yayınlarda gösterilmiştir. Bu çalışmanın amacı interatriyal blok (IAB) ve psoriazis alan ciddiyeti indeksi (PACi) arasındaki ilişkinin araştııımasıdır.

Yöntem: Ocak 2017-Mayıs 2019 arasında kardiyoloji polikliniğinde muayene olan psoriasis hastaları retrospektif olarak taranmıştır. Elektrokardiyografilerine ve PACi skorlarına ulaşılan 238 hasta çalışmaya alındı. IAB $P$ dalga süresi 120 msn üzerinde ve bifazik morfoloji eşlik ediyorsa ileri (alAB), etmiyorsa parsiyal $\mid A B(p \mid A B)$ olarak tanımlandı. $I A B ' n i n$ psoriasis hastalarında yaygınlığı ve psoriazisin şiddetiyle ilişkisi değerlendirildi.

Bulgular: Hastaların ortalama yaşı 35 (18-62) yıldı, \%53'ü erkekti.

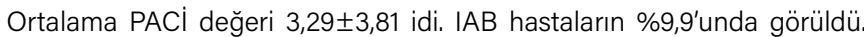
Bu hastaların \%6'sında pIAB, \%3'ünde alAB izlendi. Total IAB izlenen hastaların PACi değerleri ile IAB olmayan hastaların PACI değerleri arasında anlamlı istatistiksel fark saptanmadı $[6,0(3,0-13,5)$ vs. $7,0(2,5-$ 22,5), $p=0,35]$. Ortalama P dalga süresi (PDS) 101 (90-111) msn idi. PDS ile PACl skoru arasında istatiksel açıdan anlamlı olmayan korelasyon izlendi $(p=0,35, r=0,06)$.

Sonuç: Psoriazisin şiddetini gösteren PACi skoru ile IAB blok arasında anlamlı ilişki bulunmadı.

Anahtar kelimeler: Atriyal fibrillasyon, elektrokardiyografi, inme, interatriyal blok, psoriazis, psoriazis alan ciddiyet indeksi

Address for Correspondence: Nijad Bakhshaliyev, Bezmialem Vakıf University Faculty of Medicine, Department of Cardiology, İstanbul, Turkey E-mail: bnijad@bezmialem.edu.tr ORCID: orcid.org/0000-0001-8116-7846 Received: 16.08.2020 Accepted: 23.10.2020

Cite this article as: Bakhshaliyev N, Enhoş A, Karaçöp E, Özdemir R. The Relationship Between Interatrial Block and PASI Score in Patients with Psoriasis. Bagcilar Med Bull 2021;6(1):32-36.

${ }^{\odot}$ Copyright 2021 by the Health Sciences University Turkey, Bagcilar Training and Research Hospital Bagcilar Medical Bulletin published by Galenos Publishing House. 


\section{Introduction}

Psoriasis is a chronic, immune-mediated systemic disease of unknown etiology. It is estimated that $1-5 \%$ of the world population is affected by this disease $(1,2)$. Although it is mostly known for involving the skin and joints, recent studies have shown that the incidence of cardiovascular diseases has increased in patients with psoriasis (3). While cardiovascular risk factors are frequently observed in patients with psoriasis, it has also been recently demonstrated that there is a close relationship between psoriasis and myocardial infarction (4). These comorbid conditions additionally increase morbidity and mortality in patients with psoriasis.

$\mathrm{AF}$ is the most common cardiac arrhythmia with a demonstrated association with both morbidity and mortality in clinical practice. AF increases mortality, sudden cardiac death, heart failure, and stroke. Current studies show that AF is responsible for $20-30 \%$ of ischemic stroke (5). With appropriate anticoagulation, a reduction can be provided in thromboembolic complications. Due to its episodic nature, the diagnosis of paroxysmal AF is the challenge that delays to start an appropriate anticoagulation treatment (6).

The IAB is caused by the conduction delay on the Bachmann's bundle, which is responsible for connection of the right atrium to the left electrically (7). In one Finnish study, the prevalence of partial and advanced IAB in general population aged over 30 years was $9.7 \%$ and $1.0 \%$, respectively (8). Several studies have shown that IAB is an independent predictor of $\mathrm{AF}(9,10)$. The increased frequency of IAB has also been demonstrated in patients with silent brain infarction (11). A recently published article demonstrated an increased prevalence of partial and advanced IAB in patients with embolic stroke with undetermined source (12). In the same study, advanced $\mathrm{IAB}$ independently predicted AF (12).

This study aimed to demonstrate the relationship between the PASI score and IAB.

\section{Materials and Methods}

Patients with psoriasis who were examined at the cardiology outpatient clinic between January 2017 and May 2019 were retrospectively screened. Patients with available PASI scores and ECG recordings were included in the study. Patients with other than sinus rhythm, previous history of atrial arrythmias, structural heart diseases, hypo- and hyperthyroidism were excluded from the study. Baseline medical history and laboratory values of the patients were recorded. Standard 12-derivation ECG recordings were reevaluated.ECGs were scanned at $300 \mathrm{DPI}$, then transferred to electrophysiology (EP) calipers software (EP Studios, Inc, Version 3.1) and all measurements were performed in this software. The start of the $\mathrm{P}$ wave is the point with the first upward or downward deflection of the isoelectric line, whereas the end of the $\mathrm{P}$ wave was considered as the point where the wave returned to the isoelectric line (Figure 1). ECGs were evaluated by two different cardiologists in terms of IAB and were evaluated by a third cardiologist when there was a conflict in the diagnosis.

$\mathrm{IAB}$ was defined as if $\mathrm{P}$ wave duration (PWD) was equal to or longer than 120 msec with (advanced IAB) or without [partial IAB (pIAB)] biphasic P morphology (terminal negative deflection) in the inferior electrocardiographic leads (Leads II, III and aVF).

To calculate PASI score, the body was divided into several regions: head, upper and lower extremities and trunk. Each involved area was scored on a 0 to 6 scale. Each area was assessed in terms of erythema, infiltration and desquamation, which were scored separately on a 0 to 4 scale. Then all scores were summed up to achieve the final PASI score which was ranging from 0 to 72 . PASI $<5$ was classified as mild, PASI 5-10 as intermediate, and PASI $>10$ as severe psoriasis.

PASI scores were obtained from the previous medical records. The highest value was taken if there were multiple PASI score values.

The study was approved by Bezmialem Vakıf University Ethics Committee (no:16/297). Informed consents were

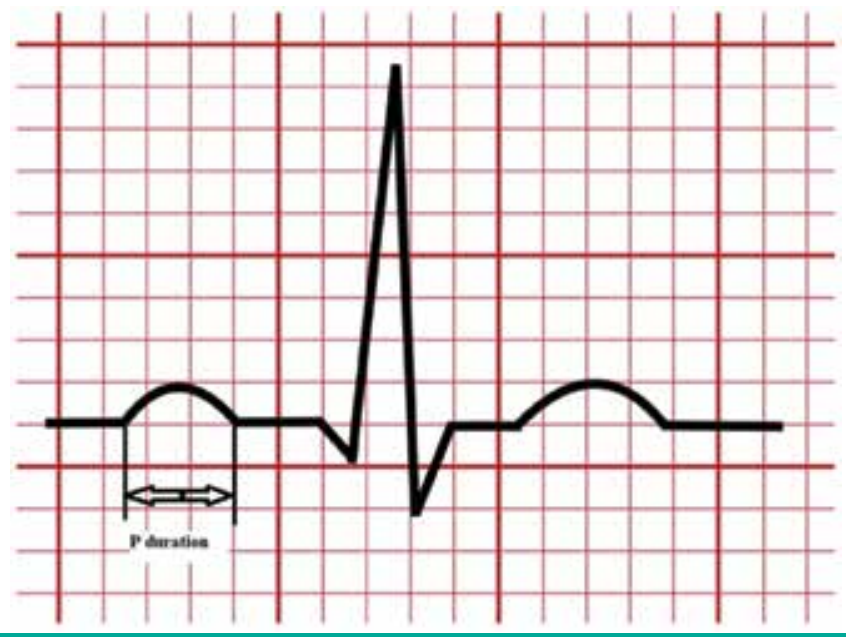

Figure 1. P wave duration measurement 
provided and the study was conducted according to the guidelines on clinical investigations of Declaration of Helsinki.

\section{Statistical Analysis}

Continuous variables were expressed as mean \pm standard deviation, while skewed variables were showed as median \pm interquartile range. The normality was tested by visual (histogram and probability graphs) and analytical methods (Kolmogorov-Smirnov or Shapiro-Wilk tests as appropriate). The Mann-Whitney $U$ test was used to compare PASI scores in patients with and without IAB. For checking correlation, the Spearman's test was used. All reported $\mathrm{p}$-values were 2 -sided and $\mathrm{p}<0.05$ was considered as statistically significant. SPSS version 20 was used to perform statistical analyses.

\section{Results}

The study evaluated 238 patients whose ECG and PASI scores and clinical information were fully available. The mean age was 35 (18-62) years, $53 \%$ of study population were male (Table 1). The median PASI score was 6. pIAB was observed in $6.9 \%$ of the patients and the prevalence of advanced IAB was $3.0 \%$. No statistically significant difference existed between the PASI score in patients with and without IAB [6.0 (3.0-13.5) vs. 7.0 (2.5-22.5)], respectively, $\mathrm{p}=0.35)$. The mean PWD was 101 (90-111) ms. No statistically significant correlation was observed between PWD and the PASI score $(\mathrm{p}=0.35, \mathrm{r}=0.06)$ (Table 2).

\section{Discussion}

The study revealed that there was no significant relationship between the PASI score and IAB. Although the PASI score is relevant to the severity of psoriasis, it varies widely with treatment. In our study, we considered the highest PASI values of the patients. This study showed that the PASI value could not predict IAB. Although the frequency of AF increased in psoriasis and the relationship of $\mathrm{IAB}$ with $\mathrm{AF}$ was shown, we found in this study that the risk of AF could not be estimated with the PASI score.

$\mathrm{AF}$ is responsible for $25 \%$ of strokes (13). Therefore, revealing the factors predicting $\mathrm{AF}$ will be effective in preventing stroke (13). The relationship between psoriasis and $\mathrm{AF}$ has been demonstrated in the Danish cohort. 36,765 patients with mild psoriasis were compared with 4,478 patients with severe psoriasis and 4,478,926 controls without psoriasis. Both $\mathrm{AF}$ and the risk of stroke were found to be high in patients with psoriasis (3). Similar results were demonstrated in the meta-analysis conducted by Upala et al. (14). A cohort study published by Egeberg et al. (15) showed an increased risk of AF and stroke in psoriasis. The risk of AF and stroke was more common in patients with psoriasis accompanied by depression.

Many studies have shown that IAB is an independent predictor of AF (9). The IAB is known for the delay of conduction on the Bachmann's pathway or the delay of the transition from right to left due to its complete block, and the PWD being longer than $120 \mathrm{msec}$ in ECG (7). Its prevalence increases with age. In a study, in which 1,353 healthy males under the age of 35 years were screened, IAB was observed in $5.4 \%$ of those under the age of 20 years and $9.1 \%$ of those under the age of 35 years (16). In this study, IAB was considered if the PWD was $110 \mathrm{msec}$ and above. In our study, the mean age of the patients was 35 years,

Table 1. Baseline characteristics of study population

\begin{tabular}{|c|c|}
\hline & Values \\
\hline Age, men (years) & $35(18-62)$ \\
\hline Gender male, $\mathrm{n}(\%)$ & $137(53.1)$ \\
\hline Hypertension, n (\%) & $23(8.9)$ \\
\hline $\mathrm{DM}, \mathrm{n}(\%)$ & $7(2.7)$ \\
\hline CAD, n (\%) & $6(2.3)$ \\
\hline CVA, n (\%) & $0(0)$ \\
\hline Hyperlipidemia, n (\%) & $10(3.9)$ \\
\hline Depression, n (\%) & $18(7)$ \\
\hline \multicolumn{2}{|l|}{ Laboratories } \\
\hline Hemoglobin, mean (g/dL) & $14.1(13.2-15.4)$ \\
\hline WBC, mean $\left(x 10^{9}\right)$ & $7.61(6.45-9.53)$ \\
\hline Neutrophils, mean $\left(x 10^{9}\right)$ & $4.31(3.53-5.31)$ \\
\hline Lymphocytes, mean (x109) & $2.27(1.89-2.76)$ \\
\hline CRP & $2(1-6)$ \\
\hline PASI score, median, (IQR) & $6.0(2.9-14.3)$ \\
\hline Advanced IAB, n (\%) & $12(4.7)$ \\
\hline Partial IAB, n (\%) & $20(7.8)$ \\
\hline Total IAB, n (\%) & $32(12.4)$ \\
\hline $\mathrm{P}$ wave duration, msn, median (IQR) & $101(90-111)$ \\
\hline
\end{tabular}

Table 2. Correlation between PASI and IAB

\begin{tabular}{|c|c|c|c|}
\hline & IAB (-) & IAB (+) & $\mathbf{p}$ \\
\hline $\begin{array}{l}\text { P wave duration, msn, } \\
\text { median (IQR) }\end{array}$ & $99(90-106.25)$ & $128.5(123-132.75)$ & $<0.001$ \\
\hline PASI, median (IQR) & $6.0(3.0-13.5)$ & $7.0(2.5-22.5)$ & 0.35 \\
\hline
\end{tabular}


while IAB was seen in $12.4 \%$ of the population. In another study, the prevalence in patients with 70-80 years of age was $37.4 \%$ (29.7\% pIAB, $7.7 \%$ aIAB), and $39.4 \%$ (19.7\% pIAB, $19.7 \%$ aIAB) in the population over 100 years of age (17). IAB prevalence varies in different patient populations. Its prevalence in the patient population with heart failure was identified to be $10 \%$ (18). Increased frequency of IAB has also been shown in patients with silent brain infarction (11). To the best of our knowledge, no study on the prevalence of IAB has been performed in the patient population with psoriasis so far.

Although it has been shown in different studies that the incidence of AF increased in psoriasis, the mechanism of this relationship could not be elucidated in detail yet. Active inflammation is thought to be involved in pathophysiology (19). Chronic inflammation is known to be effective in left atrial remodeling (20), which creates a substrate for AF. Histopathological studies performed in patients with AF have revealed inflammatory cell infiltration (21) and oxidative damage in atrial tissue (22). Inflammation causes prolonged PWD (23) and atrial electromechanical delay (24). While PWD is an electrocardiographic indicator (25) showing non-homogeneous spread of sinus stimulation, it also shows that inter- and intra-atrial conduction time is prolonged.

PASI was developed to evaluate the effectiveness of retinoid therapy in chronic plaque psoriasis (26). The prevalence (based on body surface area) and severity of psoriatic plaques are calculated by the physician separately for all four anatomical regions. The severity of erythema, desquamation and induration is scored in a 5 -point system (0- no involvement, 1- mild, 2- moderate, 3 - serious, 4- very serious). Values between 0 and 6 are assigned according to the percentage of involvement of the four anatomical regions. Zero- no involvement, $1=1-9 \%$, $2=10-29 \%, 3=30-49 \%, 4=50-69 \%, 5=70-89 \%, 6=90-100 \%$. The PASI score ranges from 0 to 72 . High scores indicate more serious disease (27). PASI is one of the most validated scales in demonstrating the severity of psoriasis. Easy of application and good correlation with other objective scales are some of the advantages of the test. However, it is among the disadvantages of the score that it cannot always accurately predict the severity of the disease in terms of the patient and does not show a linear correlation with the severity of the disease (27). However, the score is frequently used in clinical evaluations of psoriasis. It is also used in the investigation of cardiovascular morbidity and mortality in psoriasis. In a study conducted by
Al- Mutairi et al. (28), in which the data of 1,661 patients were examined, they showed that the risk of CAD was higher in patients with a PASI score of more than 10 compared to patients with a score of less than 10 .

\section{Study Limitations}

The study has all the limitations of retrograde and observational studies. Another limitation is the low number of patients. By increasing the number of samples, the probability of type II error can be reduced. Another limitation of the study is that the study is single-centered. Increasing the number of centers and samples requires the study results to be approved in a larger study.

\section{Conclusion}

No significant relationship was identified between IAB and the PASI score, which was used for assessing the severity of psoriasis in this study. It was thought that the lack of relationship might be due to the constant variability of the PASI score. Our result needs to be confirmed with larger studies.

\section{Ethics}

Ethics Committee Approval: The study was approved by Bezmialem Vakıf University Ethics Committee (no:16/297).

Informed Consent: Informed consents were provided and the study was conducted according to the guidelines on clinical investigations of Declaration of Helsinki.

Peer-review: Externally peer-reviewed.

\section{Authorship Contributions}

Concept: N.B. A.E., R.Ö., Design: N.B., E.K., A.E., Data Collection or Processing: N.B., A.E., Analysis or Interpretation: N.B., E.K., R.Ö., Writing: N.B., E.K., R.Ö.

Conflict of Interest: No conflict of interest was declared by the authors.

Financial Disclosure: The authors declared that this study has received no financial support.

\section{References}

1. Kurd SK, Gelfand JM. The prevalence of previously diagnosed and undiagnosed psoriasis in US adults: results from NHANES 20032004. J Am Acad Dermatol 2009;60(2):218-224.

2. Parisi R, Symmons DP, Griffiths CE, Ashcroft DM. Global epidemiology of psoriasis: a systematic review of incidence and prevalence. J Invest Dermatol 2013;133(2):377-385.

3. Ahlehoff O, Gislason GH, Charlot M, Jørgensen C, Lindhardsen J, Olesen JB, et al. Psoriasis is associated with clinically significant 
cardiovascular risk: a Danish nationwide cohort study. J Int Med 2011;270(2):147-157.

4. Gelfand JM, Neimann AL, Shin DB, Wang X, Margolis DJ, Troxel AB. Risk of myocardial infarction in patients with psoriasis. JAMA 2006;296(14):1735-1741.

5. Kirchhof P, Benussi S, Kotecha D, Ahlsson A, Atar D, Casadei B, et al. 2016 ESC Guidelines for the management of atrial fibrillation developed in collaboration with EACTS. Eur J Cardiothorac Surg 2016;50(5):e1-e88.

6. Murtagh B, Smalling RW. Cardioembolic stroke. Curr Atheroscler Rep 2006;8(4):310-316.

7. de Luna AB, Platonov P, Cosio FG, Cygankiewicz I, Pastore C, Baranowski R, et al. Interatrial blocks. A separate entity from left atrial enlargement: a consensus report. J Electrocardiol 2012;45(5):445-451.

8. Istolahti T, Eranti A, Huhtala H, Lyytikäinen LP, Kähönen M, Lehtimäki $\mathrm{T}$, et al. The prevalence and prognostic significance of interatrial block in the general population. Ann Med 2020;52(34):63-73.

9. De Luna AB, Guindo J, Vi olas X, Martinez-Rubio A, Oter R, BayesGenis A. Third-degree inter-atrial block and supraventricular tachyarrhythmias. EUROPACE-LONDON 1999;1:43-46.

10. Martínez-Sellés M, Elosua R, Ibarrola M, de Andrés M, DíezVillanueva P, Bayés-Genis A, et al. Advanced interatrial block and $\mathrm{P}$-wave duration are associated with atrial fibrillation and stroke in older adults with heart disease: the BAYES registry. Europace 2020; 22(7):1001-1008.

11. Çinier G, Tekkeşin Aİ, Çelik TY, Mercan Ö, Tanboğa Hİ, Günay MB, et al. Value of Interatrial Block for the Prediction of Silent Ischemic Brain Lesions. J Atr Fibrillation 2018;11(3):2037.

12. Mendieta G, Guasch E, Weir D, Aristizabal D, Escobar-Robledo LA, Llull L, et al. Advanced interatrial block: A predictor of covert atrial fibrillation in embolic stroke of undetermined source. J Electrocardiol 2020;58:113-118.

13. Marini C, De Santis F, Sacco S, Russo T, Olivieri L, Totaro R, et al. Contribution of atrial fibrillation to incidence and outcome of ischemic stroke: results from a population-based study. Stroke 2005;36(6):1115-1119.

14. Upala S, Shahnawaz A, Sanguankeo A. Psoriasis increases risk of new-onset atrial fibrillation: a systematic review and metaanalysis of prospective observational studies. J Dermatolog Treat 2017;28(5):406-410.

15. Egeberg A, Khalid U, Gislason G, Mallbris L, Skov L, Hansen P. Association between depression and risk of atrial fibrillation and stroke in patients with psoriasis: a Danish nationwide cohort study. Brit J Dermatol 2015;173(2):471-479.

16. Gialafos E, Psaltopoulou T, Papaioannou TG, Synetos A, Dilaveris P, Andrikopoulos G, et al. Prevalence of interatrial block in young healthy men< 35 years of age. Am J Cardiol 2007;100(6):995-997.

17. Martínez-Sellés M, Massó-van Roessel A, Álvarez-García J, de la Villa BG, Cruz-Jentoft AJ, Vidán MT, et al. Interatrial block and atrial arrhythmias in centenarians: prevalence, associations, and clinical implications. Heart rhythm 2016;13(3):645-651.

18. de Luna AB, Massó-van Roessel A, Robledo LAE. The diagnosis and clinical implications of interatrial block. Eur Cardiol Rev 2015;10(1):54-59.

19. Rhee TM, Lee JH, Choi EK, Han KD, Lee H, Park CS, et al. Increased risk of atrial fibrillation and thromboembolism in patients with severe psoriasis: a nationwide population-based study. Sci Rep 2017;7(1):9973.

20. Angeli F, Reboldi G, Verdecchia P. Hypertension, inflammation and atrial fibrillation. J Hypertens 2014;32(3):480-483.

21. Frustaci A, Chimenti C, Bellocci F, Morgante E, Russo MA, Maseri A. Histological substrate of atrial biopsies in patients with lone atrial fibrillation. Circulation 1997;96(4):1180-1184.

22. Mihm MJ, Yu F, Carnes CA, Reiser PJ, McCarthy PM, Van Wagoner DR, et al. Impaired myofibrillar energetics and oxidative injury during human atrial fibrillation. Circulation 2001;104(2):174-180.

23. Bacaksiz A, Erdogan E, Tasal A, Vatankulu MA, Kul S, Sevgili E, et al. Electrocardiographic P-wave characteristics in patients with psoriasis vulgaris. Ups J Med Sci 2013;118(1):35-41.

24. Aksan G, Nar G, Soylu K, İnci S, Yuksel S, Serra Ocal H, et al. Assessment of atrial electromechanical delay and left atrial mechanical functions in patients with psoriasis vulgaris. Echocardiography 2015;32(4):615-622.

25. Dilaveris PE, Gialafos EJ, Sideris SK, Theopistou AM, Andrikopoulos GK, Kyriakidis M, et al. Simple electrocardiographic markers for the prediction of paroxysmal idiopathic atrial fibrillation. Am Heart J 1998;135(5 Pt 1):733-738.

26. Fredriksson T, Pettersson U. Severe psoriasis-oral therapy with a new retinoid. Dermatology 1978;157(4):238-244.

27. Schmitt J, Wozel G. The psoriasis area and severity index is the adequate criterion to define severity in chronic plaque-type psoriasis. Dermatology 2005;210(3):194-199.

28. Al-Mutairi N, Al-Farag S, Al-Mutairi A, Al-Shiltawy M. Comorbidities associated with psoriasis: an experience from the Middle East. J Dermatol 2010;37(2):146-155. 